\title{
PENNSYLVANIA EMPLOYEES PROTECTED ABROAD: EXTRATERRITORIAL APPLICATION OF STATE LABOR LAW IN TRUMAN V. DEWOLFF, BOBERG \& ASSOCIATES, INC. AND THE FAIR LABOR STANDARDS ACT FOREIGN WORK EXEMPTION
}

Anne Thibadeau*

\section{INTRODUCTION}

Contrary to an employee's possible expectation, state and federal labor protections afforded to United States citizens may be diminished if the employer sends him or her to a different jurisdiction to perform work. The federal Fair Labor Standards Act ("FLSA") requires a rate of one and one half pay for overtime work unless an enumerated exemption applies. ${ }^{1}$ Under the FLSA, employees lose protection if the employment is "in foreign countries and certain United States territories." State wage and overtime laws modeled on the FLSA are less clear about foreign work exemptions similar to the FLSA and expand protections given to employees. ${ }^{3}$

Analysis of the precedent surrounding this labor law issue and the historical context of the FLSA $\S 213(\mathrm{f})$ exemption are necessary to exploring whether overtime and minimum wage protections may be applied to work performed abroad

\footnotetext{
* Anne Thibadeau, Graduate of the University of Pittsburgh Law School, class of 2011. I would like to thank all of my professors and, specifically, Professors Charles De Monaco and Pat Chew for their careful review of this article.

129 U.S.C. § $207(\mathrm{~g})(3)(2006)$.

29 U.S.C. § 213(f) (2006).

3 See, e.g., 43 PA. CONS. STAT. § 333.105 (2010); Pac. Merch. Shipping Ass'n v. Aubry, 918 F.2d 1409, 1420 (9th Cir. 1990) (explaining that the FLSA does not preempt more liberal California overtime laws from applying to maritime workers).
} 
U N I V E R S I T Y OF P I T T S B U R G H L A W R E V I E W

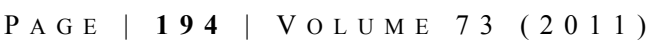

in the absence of a foreign work exemption. It is also crucial to consider the practical implications of this work exemption on the state employees and employers who live with these labor laws.

In Truman v. DeWolff, Boberg \& Associates, Inc. ${ }^{4}$ the U.S. District Court for the Western District of Pennsylvania explored the significance of the absence of an explicit foreign work exemption in the Pennsylvania Minimum Wage Act (PMWA) after Mr. Truman asserted that the PMWA overtime and minimum wage protections should apply for work that he performed in England on behalf of his employer. ${ }^{5}$ In a motion for partial summary judgment, the defendant, DeWolff, requested the court find that the PMWA overtime provisions could not be applied abroad. ${ }^{6}$ The court denied the motion and found that the PMWA did not contain an implied foreign work exemption derived from the FLSA. ${ }^{7}$ This court's decision serves as a basis for examining whether it is reasonable for a state to expand labor protections and reach farther than the FLSA in order to protect its citizens.

Part I of this note explores the history and rationale behind the FLSA $\S 213$ (f) exemption; Part II covers the pre-emption policy of the FLSA; Part III discusses both different employment situations potentially implicating the foreign work exemption and the exceptions to the FLSA exemption that allow for coverage when an employee works abroad; Part IV begins the analysis of the PMWA and Truman; and finally, Part V discusses whether the $\S 213(\mathrm{f})$ exemption in FLSA should be applied in light of the policies surrounding the FLSA, state labor laws, and prior cases. This note does not call for the removal of 29 U.S.C. $\S 213(\mathrm{f})$ from the FLSA but focuses on the motivations behind it and its impact on a state's - particularly Pennsylvania's - ability to create laws protecting its citizens while working abroad.

\section{HISTORY AND THEORY BEHIND FOREIGN WORK EXEMPTION}

In Vermilya-Brown Co. v. Connell, the Supreme Court examined whether the FLSA protections extended to employees of contractors who worked for the United

States. ${ }^{8}$ These local employees worked on a United States military base, located in

\footnotetext{
${ }^{4}$ No. Civ. 07-01702, 2009 WL 2015126 (W.D. Pa. July 7, 2009).

${ }^{5}$ See id.

${ }^{6}$ See id.

${ }^{7}$ Id. at $* 3$.

8335 U.S. 377,390 (1948).
} 
Bermuda, that had been leased to the United States by Great Britain. ${ }^{9}$ The Supreme Court held that the FLSA protections did extend to the employees because the leased territory in which they worked qualified as a "possession" of the United States and therefore was under its control..$^{10}$ The Court in Vermilya-Brown did not claim jurisdiction over United States citizens working abroad but rather over the military base territory, which led the Court to apply the FLSA. ${ }^{11}$ Vermilya-Brown does not set a precedent that jurisdiction is based on citizenship of the employee, but rather implies that jurisdiction is based on a specific geographical area and the events occurring in that area. Responding to the Vermilya-Brown decision, Congress codified a foreign work exemption in 29 U.S.C. $\S 213(\mathrm{f})^{12}$ by passing Public Law $85-231 .{ }^{13}$ In the foreign work exemption Congress restricted the FLSA in "its overseas application in certain overseas areas, and for other purposes." "14

According to Senate Report No. 85-987, the Vermilya-Brown decision raised "difficult questions of sovereignty and offend[ed] the political sensitivities of the foreign governments." 15 The rationale in the Senate Report indicates a belief that workers had been paid satisfactorily, in proportion to local government requirements, and that to pay workers under the FLSA rates would incentivize workers to abandon local jobs and create a privileged group. ${ }^{16}$ Finally, the Senate found that application of the FLSA in the Vermilya-Brown context was problematic to the Senate because it exposed American contractors to liability, conflicting with the policy of the Department of Defense that contractors performing defense work

\footnotetext{
${ }^{9}$ Id. at 380 .

${ }^{10}$ Id. at 390 .

${ }^{11}$ Bd. of Tr. of the Leland Stanford Junior Univ., Comment, Overseas Effect of Federal States, 1 STAN. L. REV. 768, 770 (1949).

12 See Pfeiffer v. Wm. Wrigley Jr. Co., 755 F.2d 554, 558-59 (7th Cir. 1985); Kimble v. Holmes \& Narver Servs., Inc., No. 92-1904, 1993 WL 211650, *1 (4th Cir. June 17, 1993) (asking whether Vermilya-Brown "remains authoritative in light of subsequent amendments to the FLSA designed to reverse the decision").

${ }^{13}$ Fair Labor Standards Act, Pub. L. No. 85-231, 71 Stat. 514 (1957) (codified as amended at 29 U.S.C. $\S 213(\mathrm{f})(2006))$.

14 Id. Originally, the act also listed Hawaii and Alaska as exempt areas, however in 1960 those two areas were removed. Pub. L. No. 86-624, 74 Stat. 411, 416-17 (1960).

15 S. REP. NO. 85-987 (1957), reprinted in 1957 U.S.C.C.A.N. 1756, 1757.

${ }^{16}$ Id.
} 
on the Bermuda military base were insured against liability by an underwriting policy of the Department of Defense. ${ }^{17}$

Since Vermilya-Brown, the Supreme Court has found that domestic United States legislation should be presumed not to apply extraterritorially unless Congress indicates otherwise. ${ }^{18}$ This presumption was considered necessary by the Court because of sensitivities to foreign affairs, feasibility of enforcement, and even fear of retaliatory conduct. ${ }^{19}$

Despite the international and administrative concerns of applying the FLSA abroad, other FLSA exemptions are generally applied more conservatively since the statute is designed to prevent detrimental working conditions and protect people who are paid less generously. ${ }^{20}$ The purpose and policy of the FLSA are recited in $\S 202(a)-(b)$ :

The Congress finds that the existence ... of labor conditions detrimental to the maintenance of the minimum standard of living necessary for health, efficiency, and general well-being of workers (1) causes commerce and the channels and instrumentalities of commerce to be used to spread and perpetuate such labor conditions among the workers of the several States; (2) burdens commerce and the free flow of goods in commerce; (3) constitutes an unfair method of competition in commerce; (4) leads to labor disputes burdening and obstructing

\footnotetext{
${ }^{17}$ Id. at 1758 ("Such contractors could be liable for failure to pay overtime rates, underpayment of wages, plus an equal amount for liquidated damages, attorneys' fees, and court costs. This possibility is a matter of great concern to the department of defense because it has underwritten its contractors against such a liability.").

18 See Equal Emp't Opportunity Comm'n v. Arabian Am. Oil Co., 499 U.S. 244, 248 (1991) (stating that absent contrary congressional intent, U.S. legislation is to apply only within U.S. jurisdiction); see also Foley Bros. v. Filardo, 336 U.S. 281, 285 (1949) (finding that the Eight Hour Law did not apply to contracts in a foreign country).

${ }^{19}$ See, e.g., McCulloch v. Sociedad Nat'l de Marineros de Honduras, 372 U.S. 10, 19-21 (1963); Foley Bros., 336 U.S. at 296-300.

20

${ }^{20}$ See, e.g., Ensinger v. Urban, 332 A.2d 484, 488 (Pa. Super. Ct. 1974) ("In applying the exemption provisions of the Fair Labor Standards Act, the courts are required to give a narrow interpretation to the terms therein."); Say v. Prior Oil Co., 43 A.2d 417, 419 n.2 (Pa. Super. Ct. 1945) (stating that the purpose of the FLSA was to ensure fair pay to workers and that any humanitarian and remedial statutes must be narrowly construed so as not to frustrate the purpose and spirit of the statute itself); Jacob Wedemeyer, Of Policies, Procedures, and Packing Sheds: Agricultural Incidents of Employer Abuse of the H-2b Nonagricultural Guestworker Visa, 10 J. GENDER RACE \& JUST. 143, 173 (Fall 2006) (discussing attempts that were made to define agriculture narrowly in the context of the agricultural worker exemption in order to include more workers in FLSA's protections).
} 
commerce and the free flow of goods in commerce; and (5) interferes with the orderly and fair marketing of goods in commerce. ${ }^{21}$

A plain reading of the FLSA demonstrates economic concerns: the statute was enacted under the power of the Commerce Clause because Congress found that poor labor conditions would negatively impact the efficiency and national health of all workers, leading to interference with interstate commerce. ${ }^{22}$ However, the FLSA was enacted as a remedial statute in order to protect wage earners who did not have the ability to negotiate for reasonable wages due to lack of bargaining power. $^{23}$

\section{The FLSA Policy on Pre-emption of State LaW}

Congress defines the FLSA's relation to other laws by determining the FLSA's pre-emptive power. Provisions of the FLSA are not intended to "excuse noncompliance with any Federal or State law or municipal ordinance establishing a minimum wage higher than the minimum wage established under this chapter or a maximum workweek lower than the maximum workweek established under this chapter." ${ }^{24}$ This statement gives more-protective state and municipal laws the power to determine the controlling wage provisions. The FLSA functions as a floor, not a ceiling, for labor protections. Section 213(f) is given special attention in subsection (b), seemingly as a direct response to Vermilya-Brown, and applies only to members of the Armed Forces or a subclass of employees in the Canal Zone. ${ }^{25}$ State laws cannot restrict protections afforded to employees under the FLSA, but states may offer greater protections to employees.

Case law surrounding the FLSA further supports this reading. ${ }^{26}$ In DeKeyser v. Thyssenkrupp Waupaca, Inc., the Court recognized the FLSA savings clause and

\footnotetext{
2129 U.S.C. $\S 202(a)$ (2006).

${ }^{22}$ Barrentine v. Arkansas-Best Freight System, Inc., 450 U.S. 728, 739 (1981).

23 See, e.g., De Leon-Granados v. Eller \& Sons Trees, Inc., 581 F. Supp. 2d 1295, 1308 (N.D. Ga. 2008); Barrentine, 450 U.S. at 739 (stating that the FLSA's purpose was to protect workers from underpayment and overwork).

2429 U.S.C. $\S 218$ (a) (2006) (emphasis added).

25 See 29 U.S.C. $\$ 218($ b) (2006).

26 See Agsalud v. Pony Exp. Courier Corp. of Am., 833 F.2d 809, 810 (9th Cir. 1987) (finding that the federal Motor Carrier Act, 49 U.S.C. $\$ 3103$ et seq., that requires overtime pay after 60-hour work weeks does not pre-empt Hawaii state law from setting overtime payments for any time worked over 40
} 
that state law "may offer an alternative legal basis for equal or more generous relief for the same alleged wrongs. ${ }^{27}$ In DeKeyser, the plaintiffs alleged violations of the FLSA and the Wisconsin Administrative Code for defendant's failure to pay overtime and the minimum wages owed under the Wisconsin Administrative Code. ${ }^{28}$ In Baxter v. M.J.B. Investors, the Court did not imply an FLSA exemption into the Oregon wage act and found that the FLSA-exempt plaintiff, working as a companion in adult foster care homes, was protected under Oregon law. ${ }^{29}$ The FLSA allows for expansion of rights by the states; FLSA exemptions are not automatically carried into state minimum wage laws. ${ }^{30}$

Case law supports the position that employees will receive a higher minimum wage than otherwise given to them under the FLSA when the state provides for the higher wage. ${ }^{31}$ Moreover, the FLSA will not "override or nullify" state laws so long as the state laws do not "contravene" the FLSA. ${ }^{32}$ While this indicates that the most protective law will be the applicable one, the statement that state laws will be applicable providing that they do not "contravene the requirements" of the FLSA could be interpreted to mean that a basic requirement for applying minimum wage and overtime provisions is that the worker performs his or her job duties in the United States. However, it is equally plausible to consider that all citizens are eligible for labor law protections and that the provision at $\S 213(\mathrm{f})$ is an exemption indicating that working domestically is not as an initial requirement for eligibility for the minimum wage and overtime provisions.

\footnotetext{
hours a week); Pettis Moving Co. v. Roberts, 784 F.2d 439, 441 (2d Cir. 1986) (“'[T]his court will not convert a federal law that regulates safety into one that preempts states from exercising their traditional powers of economic regulation."); Martinez-Hernandez v. Butterball, 578 F. Supp. 2d 816, 820 (E.D.N.C. 2008) ("[T]he FLSA does not excuse an employer's noncompliance with higher pay requirements than established by the FLSA."); Cranford v. City of Slidell, 25 F. Supp. 2d 727, 729 (E.D. La. 1998) (holding that the municipality had to pay the police officers in accordance with Louisiana law, rather than the FLSA, because "Louisiana law was more generous than the FLSA"); Plouffe v. Farm \& Ranch Equip. Co., 570 P.2d 1106, 1109-10 (Mont. 1977) (finding the FLSA exemption concerning the employee's sale and repair of farm protection did not pre-empt the requirements of the Montana Minimum Wage and Hours Act).

27589 F. Supp. 2d 1026, 1030-31 (E.D. Wis. 2008).

${ }^{28}$ Id. at 1029.

29876 P.2d 331, 336-37 (Or. Ct. App. 1994).

${ }^{30}$ See, e.g., Williams v. W.M.A. Transit Co., 472 F.2d 1258 (D.C. Cir. 1972).

3129 C.F.R. $§ 778.5$ (2010).

${ }^{32}$ Id.
} 


\section{EMPloyment SituATIONS OF DOMESTIC WORKERS ABROAD AND FLSA FOREIGN WORK COVERAGE}

In Truman, the plaintiff claimed he was a resident of Pennsylvania and worked at a domestic company but performed business abroad for over a week. ${ }^{33}$ The Truman court looked to whether Mr. Truman was a "Pennsylvania-based employee" working abroad, ${ }^{34}$ indicating that there are two employment situations for Pennsylvania workers: those based within the state working abroad and those physically working within the State. ${ }^{35}$

The FLSA at $\S 213(\mathrm{f})$ provides an exemption to employers located in a foreign country or jurisdiction of the United States from the FLSA provisions establishing minimum wage; overtime rates; certain investigations concerning wages, hours, and conditions; and child labor provisions that restrict employers from using oppressive child labor in production of goods. ${ }^{36}$ Although the broad language used in the FLSA appears to exclude all work performed in certain areas, there are exceptions to $\S 213$ (f). In Wirtz v. Healy, the Healys operated a tour company that offered tour packages with escorts who would accompany customers abroad. ${ }^{37}$ The escorts began and finished the tour in Chicago. ${ }^{38}$ The Court found that the escorts who performed services in both the United States and an FLSAexempt area during that same week were entitled to the FLSA benefits for both the work performed in the United States and abroad. ${ }^{39}$ However, when the escort spent the entire workweek in a foreign country, the $\S 213(\mathrm{f})$ exemption applied and, consequently, that worker was denied the FLSA protections. ${ }^{40}$ A United States citizen is exempt from the FLSA overtime and minimum wage protections once the

33 Truman v. DeWolff, Boberg \& Assocs., Inc., No. Civ. 07-01702, 2009 WL 2015126, *1 (W.D. Pa. July 7, 2009).

34 Id. at $* 3$.

${ }^{35}$ See id.

${ }^{36}$ See 29 U.S.C. § 213(f) (2006).

37227 F. Supp. 123 (N.D. Ill. 1964).

${ }^{38}$ Id.

39 Id. at 129 ("Thus, when a tour escort of defendants spends part of a workweek with a tour in the United States, it makes no difference where the remainder of such work in that week is performed; the tour escort is entitled to the benefits of the Act for the entire week.") (referencing both Vermilya-Brown Co. v. Connell, 335 U.S. 377 (1948) and 20 C.F.R. § 776.6 n.20 (2010)).

${ }^{40}$ Id. at 129. 
U N I V E R I T Y OF P I T T S B U R G H L A W R E V I E W

PAGE

citizen passes the threshold of working a full week abroad; however, he or she receives the FLSA protections if the work in the exempt area is performed the same week as work completed domestically. ${ }^{41}$

In De Leon-Granados v. Eller \& Sons Trees, Inc., the plaintiffs, who were not United States citizens but physically worked within the United States, invoked the $\S 213(\mathrm{f})$ exemption against a United States employer for unpaid visa expenses incurred in foreign jurisdictions, predominantly Guatemala. ${ }^{42}$ The U.S. District Court for the Northern District of Georgia found that the §213(f) exemption could not be invoked and recharacterized the situation as depending on the failure to reimburse the employees after their arrival to the United States, rather than the failure to pay for visas in foreign countries. This change of focus to reimbursement avoided extraterritorial application of FLSA. ${ }^{43}$ This decision leaves open the possibility that individual state labor laws could apply if a court could construe an event as somehow occurring within the state instead of abroad. Additionally, the $\S 213$ (f) exemption may not apply to seapersons or to those who work on ships, even when the ship is located in an exempt area, because the § 213(f) exemption concerns geographical locations and not specifically employees on vessels; locations of vessels are fleeting. ${ }^{44}$

Although United States citizens and state residents are generally unprotected under the FLSA when they work in an exempt geographical location, there are exceptions to this rule, as seen in cases like Wirtz ${ }^{45}$ and De Leon-Granados. ${ }^{46}$ Even if the $\S 213(\mathrm{f})$ exemption was hypothetically presumed to apply to state-level labor laws, state labor laws may still apply abroad through exceptions carved out of the $\S 213(\mathrm{f})$ FLSA exemption. For example, a person working less than a week abroad may not only be protected under the FLSA but may also have protections under

\footnotetext{
4129 U.S.C. § 213(f) (2006).

42581 F. Supp. 2d 1295, 1310-11 (N.D. Ga. 2008).

${ }^{43}$ Id

44 See Kaluom v. Stolt Offshore, Inc., 474 F. Supp. 2d 866, 880 (S.D. Tex. 2007); but see Cruz v. Chesapeake Shipping Inc., 738 F. Supp. 809, 822-23 (D. Del. 1990) (applying the FLSA § 213(f) exemption to seamen who participate in trips between two foreign countries in foreign waters).

${ }^{45}$ Wirtz v. Healy, 227 F. Supp. 123, 129 (N.D. Ill. 1964).

${ }^{46}$ De Leon-Granados, 581 F. Supp. 2d at 1310.
} 
individual state laws. ${ }^{47}$ The foreign work exemption has not been interpreted to preclude federal or state protections in every situation that a person works while abroad.

Extraterritorial application of United States employment law has been accepted in certain situations involving federal employment discrimination laws. Unlike the FLSA, the Age Discrimination in Employment Act (ADEA) applies to foreign corporations, provided that the corporations are controlled by firms located within the United States. ${ }^{48}$ Additionally, Congress enacted $\S 109$ of the Civil Rights Act of 1991, extending Title VII and the American Disabilities Act (ADA) to some U.S. citizens employed abroad, ${ }^{49}$ after the Supreme Court held that Title VII did not apply extraterritorially in Equal Employment Opportunity Commission v. Arabian American Oil Co ${ }^{50}$ Finally, in Torrico v. International Business Machines Corp. ${ }^{51}$ the U.S. District Court for the Southern District of New York interpreted the ADA as capable of application abroad. ${ }^{52}$

Both the ADEA and Title VII protections are extended if the American employer controls the workplace in the foreign country. Control is based on factors enumerated in the statute, including "(A) the interrelation of operations; (B) the common management; (C) the centralized control of labor relations; and (D) the common ownership or financial control, of the employer and the corporation." The ADEA restricts application "where the employer is a foreign person not controlled by an American employer." ${ }^{, 54}$ Title VII only applies abroad when the

${ }^{47}$ Williams v. W.M.A. Transit Co., 472 F.2d 1258, 1266 (D.C. Cir. 1972) (discussing a willingness to embrace this type of application when holding that interstate drivers regularly spending more than fifty percent of the week in the District of Columbia are protected under the District of Columbia Minimum Wage Act).

48

48 Paul D. Snitzer, The Foreign Corporation in the United States: Here to do Business, to Discriminate, or to do Both?, 13 LAB. LAW. 445, 450 (1998).

49 See Civil Rights Act of 1991, Pub. L. No. 102-166, 105 Stat. 1071 (1991) (codified as amended at 42 U.S.C. § 20003(f) (2006)).

50499 U.S. 244 (1991).

51213 F. Supp. 2d 390, 397-98 (S.D.N.Y. 2002).

${ }^{5}$ Id.

5342 U.S.C. § 2000e-1(c) (2006); 29 U.S.C. § 623(h)(3)(A-D) (2006).

5429 U.S.C. § 623(h)(2) (2006). 
U N I V E R S I T Y O F P I T T S B U R G H L A W R E V I E W

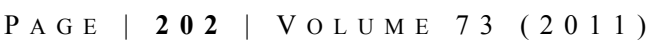

employee is a United States citizen. ${ }^{55}$ Another exception to the application of the ADEA, ADA, and Title VII is that the employer will not be held liable if compliance with one of these federal laws would cause the employer to violate the relevant foreign law. ${ }^{56}$ Although the FLSA has an explicit exemption, other antidiscrimination statutes in the employer-employee context do provide protections to citizens working abroad. The Torrico court compared the ADA, Title VII, and the FLSA and reasoned that while the ADA and Title VII apply to "employment in a foreign country," $" 57$ the $\S 213$ (f) exemption in the FLSA exempts services "performed in a workplace within a foreign country," and so the statutes were distinguishable. ${ }^{58}$ However, the Torrico court's distinction relies on the specific language of the $\S 213$ (f) exemption. Since this language is not in all state laws, Torrico may not be persuasive in prohibiting application of state overtime and minimum wage laws abroad. ${ }^{59}$

\section{Pennsylvania Overtime And the Foreign Work EXEMPTION AND THE FLSA}

The Pennsylvania Minimum Wage Act (PMWA) guarantees the same overtime rate that the FLSA provides, one and one half the regular salary for overtime after the maximum 40 hours are worked. ${ }^{60}$ Additionally, as with the FLSA, the exemptions to the PMWA protections are to be applied narrowly. In Davis v. Sulcowe, the Pennsylvania Supreme Court recognized that the PMWA was originally enacted to offer protections to women and minors and thus "any section granting exemptions under the Act must be strictly construed against those claiming exemption." ${ }^{61}$ Similar to the FLSA, the PMWA is a remedial statute, and it would frustrate the purpose of the PMWA to fail to consider inequitable

\footnotetext{
5542 U.S.C. $\S 2000 \mathrm{e}-1$ (a) (2006).

${ }^{56}$ See 42 U.S.C. $\S 12112(\mathrm{c})(1)$ (2006); 42 U.S.C. § 2000e-1(b) (2006); David A. Lowe, Enforcing the Employment Rights of American Workers Abroad, 24 LAB. LAW. 213, 214 (2008).

57

42 U.S.C. § 12111(4) (2006); 42 U.S.C. §§ 2000e(f) (2006).

${ }^{58}$ Torrico v. Int’l Bus. Mach. Corp., 213 F. Supp. 2d 390, 402 (S.D.N.Y. 2002).

${ }^{59}$ See id.

${ }^{60}$ Compare 43 PA. CONS. STAT. $\S 333.104$ (c) (2010), with 29 U.S.C. $\S 207(\mathrm{~g})(3)$ (2006).

61205 A.2d 89, 90-91 (Рa. 1964).
} 
bargaining power of the employees or to construe ambiguities against the public health. ${ }^{62}$

Despite many similarities to the FLSA, the PMWA does not have an exemption for work performed in foreign territories. ${ }^{63}$ As a result of the absence of the foreign work exemption, the U.S. District Court for the Western District of Pennsylvania held that the $\S 213$ (f) FLSA exemption should not be implied into the PMWA. $^{64}$ In Truman v. DeWolff, Boberg \& Associates, Inc., the court denied a motion for partial summary judgment, finding that the defendant company had failed to show that Mr. Truman was an exempt employee under the PMWA, even though Mr. Truman was exempt from the FLSA protections for his work performed in England and Canada.$^{65}$ Unlike the escort tour case, Wirtz v. Healy, in which the court found that the FLSA protections still applied when the worker split the work week between an exempt and non-exempt area, ${ }^{66} \mathrm{Mr}$. Truman spent entire weeks working in England and Canada. ${ }^{67}$ However, Mr. Truman was potentially based in Pennsylvania during the period he was working overtime in foreign countries, ${ }^{68}$ Mr. Truman was potentially protected by Pennsylvania law, despite his physically working outside of Pennsylvania and DeWolff, Boberg \& Associates being incorporated in Delaware. ${ }^{69}$

The Truman court decided that the PMWA did not contain an implied exemption on foreign work despite the precedent that workers who spend a full week abroad are exempt from the FLSA protections during that period. ${ }^{70}$ The Truman court cited Friedrich v. U.S. Computer Systems, Inc., in which the District Court for the Eastern District of Pennsylvania construed the PMWA to extend to

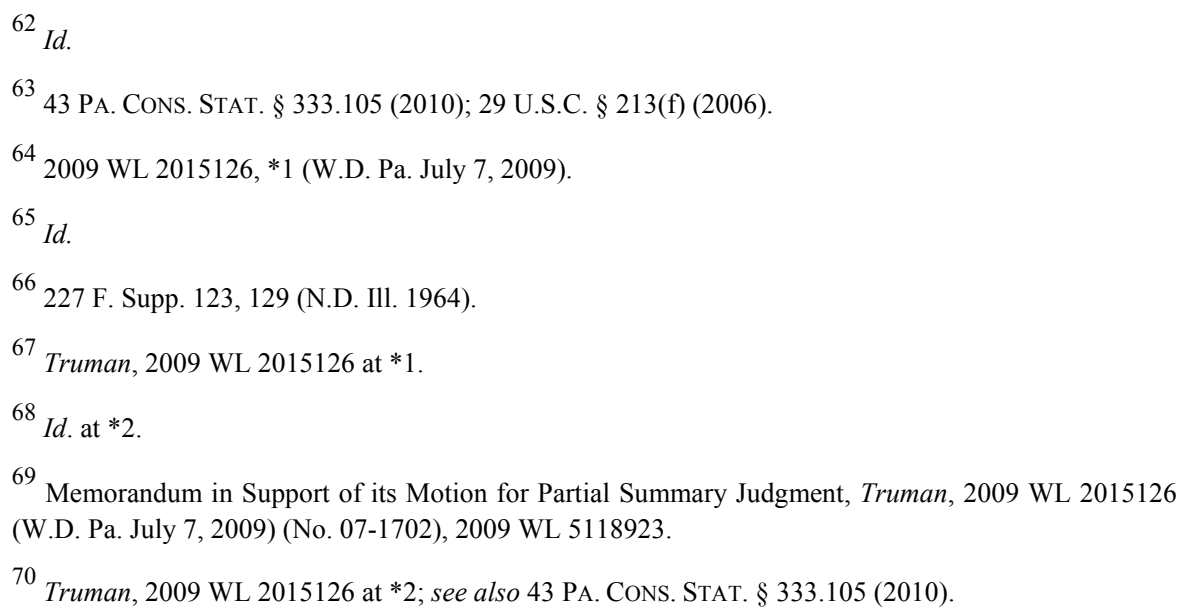


non-resident Pennsylvania employees working outside of Pennsylvania. ${ }^{71}$ Although Friedrich did not expand application of the PMWA on an international level, ${ }^{72}$ the Truman court used the persuasive value of Friedrich, the lack of an express exemption, and other case law to find the PMWA protection applied to Mr. Truman. ${ }^{73}$ The Truman court could have held that the exemption was implied from the FLSA, due to international sensitivities, or reasoned that the federal law directly contradicted Pennsylvania law. However, a plain reading of the PMWA and case law supporting the expansion of Pennsylvania labor law outside of the state led to the opposite conclusion. ${ }^{74}$

The interplay between the FLSA and the PMWA is explained by the court's statement in Friedrich v. U.S. Computer Systems, Inc. ${ }^{75}$ In Friedrich, the defendant argued that a prior definition of employee under the PMWA required that one was an employee only "to the extent that [she or] he is subject to" the FLSA. ${ }^{76}$ The defendant stressed that, despite the amendment to the definition of employee, the plaintiff was subject to the motorcar exemption under the FLSA and therefore the PMWA could not apply. ${ }^{77}$ The U.S. District Court for the Eastern District of Pennsylvania disagreed, rejecting the defendant's argument and reasoning that acceptance of that proposition would result in the PMWA ceasing to apply to all workers in interstate commerce. ${ }^{78}$ The court emphasized the underlying policy of the PMWA and stated that if the FLSA provided all of the protections that the Pennsylvania legislature could have offered its employees, there would have been no purpose to passing the PMWA. ${ }^{79}$ The Friedrich court went on to find that " $[t]$ he Pennsylvania legislature enacted the PMWA to protect those employees who do




not benefit from federal protection" and that the employees who were unprotected under FLSA were protected under state law. ${ }^{80}$ While the defendant company in Friedrich was based in Pennsylvania, the employee plaintiffs were not residents of Pennsylvania; nevertheless, the court considered them to be based in the Commonwealth for the purposes of the PMWA. ${ }^{81}$

Similarly, a person falling outside the FLSA protections due to not working within the protected locations enumerated by $\S 213(\mathrm{f})$ is not "subject to" the FLSA in such a way as to remove all of the PMWA protections. As in Friedrich, ${ }^{82}$ the PMWA can provide protections to employees not covered under the FLSA. Policy and international concerns aside, to imply exemptions in the PMWA simply because they exist in the FLSA would reduce all protections that the Pennsylvania legislature deems necessary and vitiate state power. ${ }^{83}$ Federal law concerning wage and labor would become a ceiling, contrary to the purpose of the FLSA. ${ }^{84}$ Nothing in the plain text of the PMWA seems to contradict the result, and the FLSA has generally allowed states to expand, but not restrict, federally guaranteed protections. ${ }^{85}$ In that sense, Truman's result is supported by and not contrary to federal law.

Other factors support the Truman court's decision. Although silence is not definitive, the definitions of "employee" and "employer" in the PMWA do not define employees or employers to only include those living in Pennsylvania. ${ }^{86}$ Additionally, the section providing overtime exemptions does not mention work done abroad. ${ }^{87}$

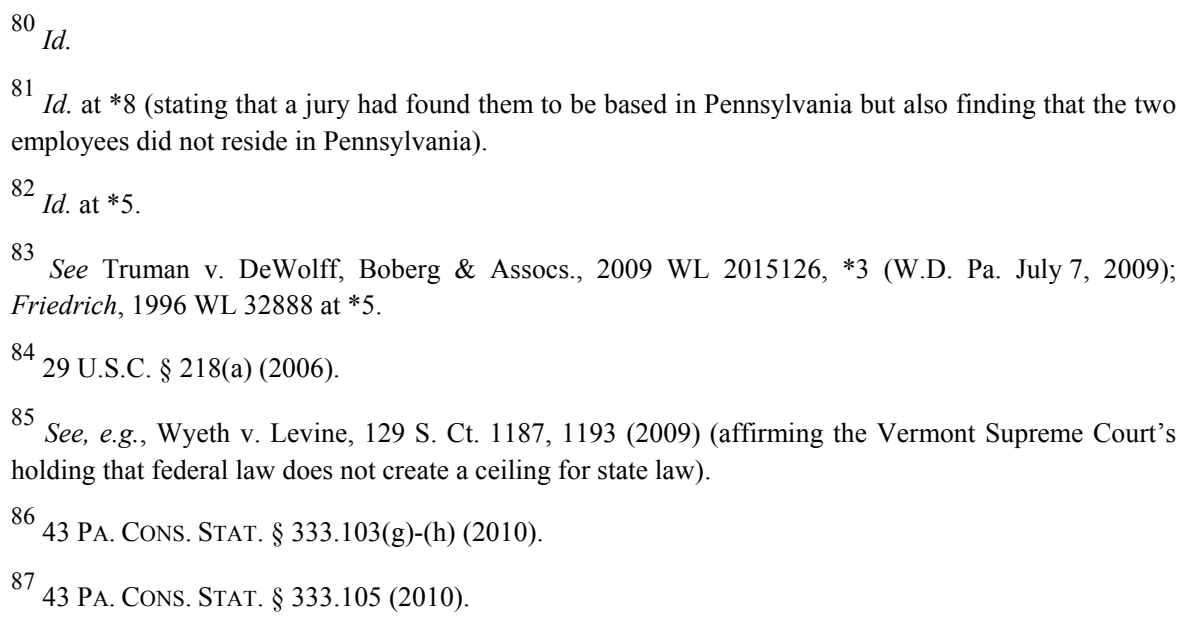


U N I V E R I T Y OF P I T T S B U R G H L A W R E V I E W

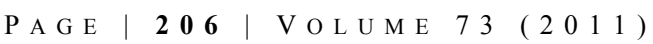

The PMWA's Declaration of Policy both supports and vitiates arguments set forth in Truman. ${ }^{88}$ The section implies that employees need additional protections because they have reduced bargaining power and that employers' suppression of fair pay harms economic stability. ${ }^{89}$ This statement reinforces pro-employee sentiment and supports the idea that this title was set in place purely for the protection of employees and that their protections, being paramount, should not be unfairly restricted. However, the statute also states that " $[t]$ he evils of unreasonable and unfair wages as they affect some employes [sic] employed in the Commonwealth of Pennsylvania . . . render imperative the exercise of the police power of the Commonwealth for the protection of industry and of the employes [sic] employed therein." ${ }^{\prime 0}$ The need to protect employees and support the community is affirmed by this section, but the PMWA discusses employment within the Commonwealth of Pennsylvania, specifically referring to "employes [sic] employed therein." ${ }^{.91}$ One can be employed within Pennsylvania and still make trips for his or her employer to another country in order to do business, and the state of employment does not change. That the payment is coming out of a Pennsylvania company's pocket and going into a resident's is similarly unaltered. Moreover, unfair competition remains an issue if an employer can avoid overtime payments merely by sending its employees to areas with less-stringent overtime laws for business.

An issue that arises in light of Truman is how to measure whether a person is a Pennsylvania-based employee or a resident of another state that might provide its own overriding labor protections. From May 22, 2006, until November 19, 2006, Truman worked in England, and for one week in January he worked in Canada. ${ }^{92}$ DeWolff's memorandum in support of the partial summary judgment motion implies that he worked domestically during the other months of his employment but does not specify where Truman was traveling to meet with clients or time spent in each area. ${ }^{93}$ Notably, memoranda for motions by the defendants concerning

88 See 43 PA. CONS. STAT. $§ 333.101$ (2010).

${ }^{89}$ See id.

${ }^{90} I d$. (emphasis added).

${ }^{91}$ Id.

92 Memorandum in Support of its Motion for Partial Summary Judgment at 9 4, Truman v. DeWolff, Boberg \& Assocs., 2009 WL 2015126 (W.D. Pa. July 7, 2009) (No. 07-1702), 2009 WL 5118923.

${ }^{93}$ Id. 
summary judgment did not raise the issue of whether there was residency status or whether employment was based in Pennsylvania.

The idea of a Pennsylvania-based employee is considered in Friedrich v. U.S. Computer Systems, in which the defendant argued that judgment should be entered against the plaintiffs because they were not based in Pennsylvania. ${ }^{94}$ Other states confronted with this issue may decide that application turns on citizenship of the state rather than whether the actual work takes place in that area. ${ }^{95}$ The court in Freidrich found that because of the failure to deny procedural defects in the case, including the failure to deny an affirmative defense, pre-trial memorandum, or proposed jury instructions, the plaintiffs were based in Pennsylvania; the defense had effectively waived the issue of where the employee was based. ${ }^{96}$ The plaintiffs were not state residents, but whether they were based in Pennsylvania was a jury finding to be supported by evidence presented by the plaintiffs. ${ }^{97}$ Freidrich stands for the precedent that employees based in Pennsylvania will receive protections regardless of residency, and that Commonwealth-"based" employment is a jury determination. ${ }^{98}$ The Truman court was not required to explore actual residency status or clearly define what constituted being based in Pennsylvania for employment purposes, as whether or not Truman was a Pennsylvania-based employee was a possible issue for the future jury to decide.

\section{SHOULD THE Foreign WORK EXEMPTION IN THE FLSA Pre-empt State Minimum Wage LaWs?}

In Tidewater Marine Western, Inc. v. Bradshaw, ${ }^{99}$ the California Supreme Court explored the FLSA's effect on the ability of the California Industrial Welfare Commission, a state agency, to formulate wage orders that were enforced by the Division of Labor Standards Enforcement in California. The Tidewater court dealt

\footnotetext{
${ }^{94}$ Friedrich v. U.S. Computer Sys., Inc., No. 90-1615, 1996 WL 32888, *8 (E.D. Pa. Jan. 22, 1996).

95

See, e.g., Parry v. Outback Steakhouse of Fla., Inc., No. 8:06-CV-00804-T-17TBM, 2006 WL 2919018 (M.D. Fla. Oct. 11, 2006) (holding that Fla. Stat. $§ 760.01$ applied extraterritorially to a woman who had been relocated by Outback Steakhouse of Florida to work in the Cayman Islands for over a year; she had retained her Florida driver's license, was a registered Florida voter, and maintained motor vehicle registration in Florida).

96 Friedrich, 1996 WL 32888 at *8.

${ }^{97}$ Id.

${ }^{98}$ See id.

99927 P.2d 296, 300 (Cal. 1996).
} 
U N I V E R S I T Y OF P I T T S B U R G H L A W R E V I E W

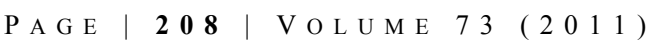

with whether the seapersons, who were outside of California State boundaries according to the federal definition of California boundaries, were subject to California law. ${ }^{100}$ The California Supreme Court found that California's determination of the location of state boundaries controlled because the issue at stake involved California state law. ${ }^{101}$ In so deciding, the Court stated that, provided there was no direct conflict with acts of Congress, nothing precluded a state from "regulating conduct beyond its borders," because California had an interest in the conduct of its citizens. ${ }^{102}$

The Tidewater court found there was no actual conflict with the FLSA, despite seapersons being exempt from the FLSA minimum wage and overtime protections in section 213(b)(6). ${ }^{103}$ The Court found that the FLSA did not expressly restrict the power of the states to regulate overtime for seamen and the legislative history of the FLSA did "not suggest an implicit preclusion." 104 Instead, the legislative history indicated that Congress added this exemption for seapersons based on the requests of labor unions. ${ }^{105}$

As in Tidewater, an important issue in Truman is whether Congress, in legislative history or expressly, has indicated an intention to restrict Pennsylvania from regulating the conduct of its citizens who work extraterritorially. Nothing in the FLSA explicitly restricts Pennsylvania's right to offer extraterritorial protections to its residents under the PMWA or other state laws. Instead, the PMWA is in compliance with the FLSA due to the FLSA savings clause. ${ }^{106}$ There is no express provision in the statutory text of the FLSA specifying that the states cannot modify this exemption.

The legislative history regarding $§ 213(\mathrm{f})$ is less clear. Legislative history demonstrates a focus on "native workers in overseas locations" instead of U.S. citizens ${ }^{107}$ and does not expressly show that Congress intended to restrict the states'

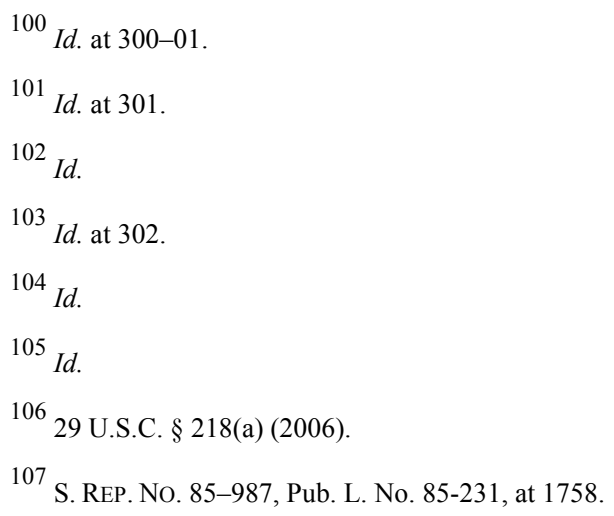


power to create state equivalents to the FLSA that do not include the foreign work exemption. ${ }^{108}$ However, the Senate committee also expressed concerns that extension of the FLSA to overseas locations did not further the goals of the FLSA. ${ }^{109}$ Arguably, if a state law is closely modeled on the FLSA, the same assumption can apply: that extraterritorial application of the state law fails to serve the purposes for which the state law was enacted. Congress may have found it unnecessary to discuss the states' powers regarding this exemption because of presumptions against extraterritorial application. ${ }^{110}$

The FLSA exception that overtime and wage protections only apply extraterritorially if the worker spends less than a full workweek in a foreign jurisdiction is mirrored in case law. In a case in the U.S. Court of Appeals for the District of Columbia, the court held that bus drivers who spent more than $50 \%$ of their workweek in the District of Columbia were protected by the District of Columbia Minimum Wage Act. ${ }^{111}$ Arguably, it is consistent with the FLSA that the local state laws should not extend extraterritorially, whether within the United States or internationally, if the worker spends the entire workweek or more working outside of the particular state. However, the District of Columbia decision is not binding on Pennsylvania courts, even though the D.C. Act was similarly patterned on the FLSA. ${ }^{112}$ Additionally, the D.C. Circuit refused to import from the FLSA the exemption refusing protections to a particular class of workers from the FLSA and noted that residents of states have both the FLSA and expanded state protections. ${ }^{113}$

The court in Williams v. W.M.A. Transit requested supplementary memoranda from the parties and cited from that memoranda information from the Maryland attorney general noting that FLSA exempt employees were covered by Maryland

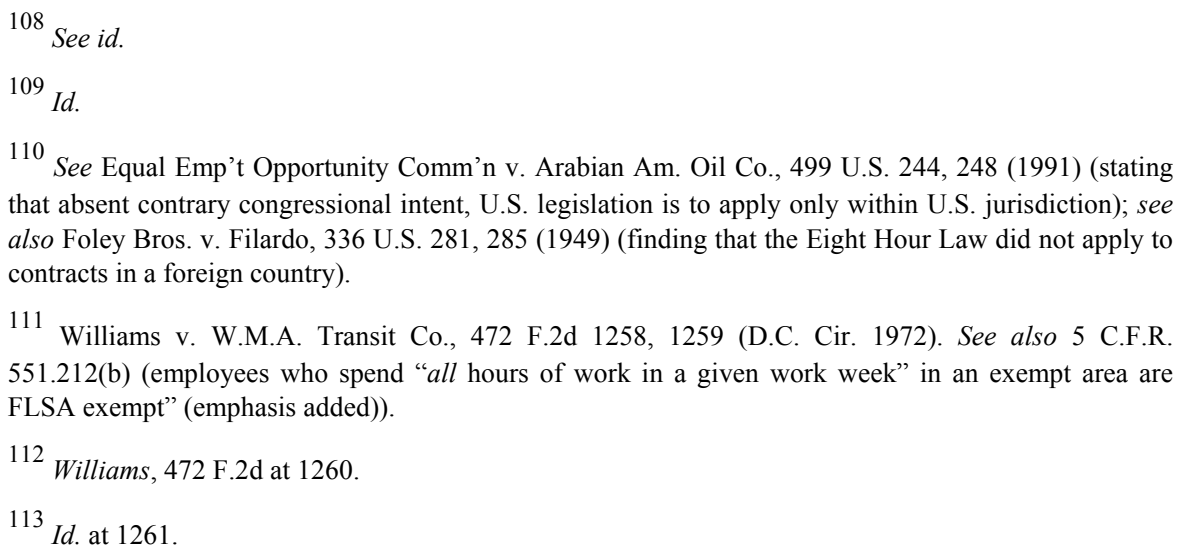


law, provided the Maryland Wage and Hour Law did not preclude coverage. ${ }^{114}$ Even when the employment was exempt from the FLSA and subject to the jurisdiction of other federal agencies, the employment was still protected by the Maryland Wage and Hour Laws. ${ }^{115}$ The Court rejected the idea that an employee was not employed in the District of Columbia unless the employment was "entirely within the District of Columbia." 116 Instead, the court decided that being employed within the District of Columbia meant that the employee regularly spent $50 \%$ or more of his or her work time within the District. This definition also helped to preserve the overall purpose of the D.C. Act, which was to minimize negative economic impacts on other employers in the area who followed the D.C. Act. ${ }^{117}$

In another District of Columbia case, the court looked at similar factors to those examined by the Tidewater court. In Environmental Defense Fund, Inc. v. Massey, the D.C. Circuit listed three instances where the presumption against extraterritorial application did not apply: instances where Congress has clearly expressed the intention to extend the scope of the statute to conduct occurring in different nations, where failure to extend the scope of the statute to a foreign setting will result in adverse effects, and where the conduct regulated by the government occurred within the United States. ${ }^{118}$ Despite the FLSA savings clause, it does not seem that the lack of a foreign exemption falls into the first category mentioned in Masey. However, the second category, looking to adverse effects caused by failure to apply the law extraterritorially, could apply to the Truman situation and was also applied by the Supreme Court in Hartford Fire Insurance Co. v. California. ${ }^{119}$

Hartford Fire Insurance Co. involved the application of the Sherman Act, which is not applied to foreign trade unless the conduct involving the foreign trade has a "direct, substantial, and reasonably foreseeable effect" on commerce domestically. ${ }^{120}$ In that case, despite arguments that application of American

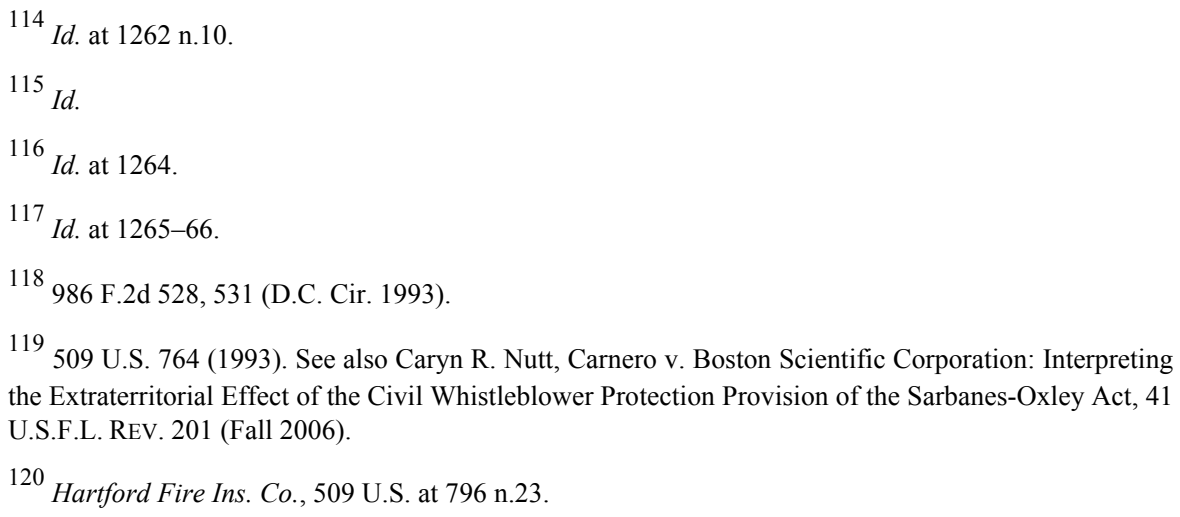


antitrust laws would conflict with English law, the Supreme Court upheld application of the Sherman Act because of the effect on United States commerce. ${ }^{121}$

The state level FLSA equivalents could affect state minimum wage and overtime protections available to domestic employees. If the employer could avoid all wage and overtime protections by basing the employee abroad for the entire workweek then the employer would gain an unfair advantage over other domestic employers within the state that did not move the workers to a FLSA exempt area. The resident employees who were forced to spend over a full workweek abroad would have different protection from workers who did not leave the state to complete their work.

One court has stated that the purpose of the PMWA was intended to protect women and children who would be discriminated against and treated unfairly or others that had impaired bargaining power in the workplace. ${ }^{122}$ Both the ADEA and Title VII were also enacted to protect certain employees from being discriminated against based upon physical characteristics, age, sex, disability, or origin. ${ }^{123}$ These statutes do apply extraterritorially, depending on the level of employer control, ${ }^{124}$ and have similar savings clauses to the FLSA. ${ }^{125}$

The federal district court in Torrico v. International Business Machine Corporation held that the New York State Human Rights Law can be applied abroad even when the employee at issue is merely domiciled in New York and is not a citizen of the United States. ${ }^{126}$ The court invoked the exceptions from Massey that the presumption against extraterritoriality may not apply if the conduct occurred, or adverse effects would occur, within the United States. ${ }^{127}$

\footnotetext{
${ }^{121}$ Id. at $797-98$.

122 Davis v. Sulcowe, 205 A.2d 89, 90-91 (Pa. 1964). See also Milton J. Shapp, OpINIONS OF THE ATTORNEY GENERAL OF PENNSYLVANIA 92 (1976), available at http://search.attorneygeneral.gov/ Documents/AG\%20Opinions/PA_Official_Opinions_of_the_Attorney_General_1976.pdf.

12342 U.S.C. § 2000e-16a(b) (2006) (limiting discrimination based upon physical characteristics, age, sex, disability, or origin); 29 U.S.C. § 621 (2006) (restricting discrimination against people based on age).

${ }^{124} 42$ U.S.C. $\S 2000 \mathrm{e}-1$ (c) (2006); 29 U.S.C. § 623(h)(3)(A-D) (2006).

12542 U.S.C. § 2000e-7 (2006); 29 U.S.C. § 623 (2006).

${ }^{126} 213$ F. Supp. 2d 390, 397 (S.D.N.Y. 2002).

${ }^{127}$ Id.
} 
U N I V E R S I T Y OF P I T T S B U R G H L A W R E V I E W

PAGE

\section{CONCLUSION}

Historically, the employer-employee relationship was regulated through state law. ${ }^{128}$ State law continues to play an important role in governing employment law in the absence of adequate federal law solutions to certain issues. ${ }^{129}$ The decision of whether to apply state minimum wage acts, without explicit foreign work exemptions, in other jurisdictions is influenced by the historical and modern importance of state law in regulating labor law, the FLSA savings clause, and the presumption against extraterritorial application. ${ }^{130}$

If state law controlled overtime and minimum wage outside of the state, employers could face difficulty in keeping track of what laws apply to which employees. Classification of the employees may not even be clear, at this point. In Friedrich, it was not entirely clear what qualified as a Pennsylvania-based employee and whether that was the best standard. ${ }^{131}$ Employers would have to be provided with clear standards to determine if employees are state residents, whether employees are based within the state, and applicable state law if the employee is not based in Pennsylvania. Ambiguity in this area could encourage litigation during a time when employees may be bringing increasing numbers of wage and hour cases. $^{132}$

The Truman result is also not entirely beneficial to Pennsylvania employees. For instance, employers may try to avoid payment by contracting outside of the company or not even hiring the employee. However, that must be weighed against the strong risk that an employee could reasonably assume that if he or she is assigned to a project out of the state, the labor protections would not be lessened, since the employer prompted the traveling and the project. Finally, an employee

\footnotetext{
${ }^{128}$ Henry H. Drummonds, The Sister Sovereign States: Preemption and the Second Twentieth Century Revolution in the Law of the American Workplace, 62 FORDHAM L. REV. 469, 509 (Dec. 1993) (asserting that "state legislatures and judges often, indeed most often, decide the appropriate mix between the free market and government intervention. Thus, far from being a marginal or interstitial aspect of our system of workplace governance, state law often plays a vital and 'leading edge' role.").

${ }^{129}$ Id. at 508-09.

${ }^{130}$ See Equal Emp't Opportunity Comm'n v. Arabian Am. Oil Co., 499 U.S. 244 (1991).

131 See Friedrich v. U.S. Computer Sys., Inc., No. 90-1615, 1996 WL 32888, *8 (E.D. Pa. Jan. 22, 1996).

132 Brian S. Arbetter \& Andrew J. Boling, Emerging Trends in Wage and Hour Cases and Defense, Aspatore, 2010 WL 284486 (Jan. 2010) (stating that the economic downturn has led to an increasing number of laid-off employees who are willing to file against previous employers).
} 
often lacks bargaining power, since the employer has the power to fire the employee and the employee generally lacks equal financial and legal resources.

The Truman case also seems to be following an evolving pro-employee attitude and willingness to give coverage to those working abroad. For instance, in 2009 a court refused to allow "a group of contractors working on a military base in Iraq" to recover damages, but then allowed a class action suit to be brought under California state law. ${ }^{133}$

This article has not explored all of the concerns surrounding international sensitivities, or the concern that by applying state-law overtime protections in foreign countries, the authority for the United States to apply the FLSA and state laws to migrant workers in the United States is impaired. The FLSA and state laws are applied to migrant workers ${ }^{134}$ and, whether that is to reduce competition for local workers ${ }^{135}$ or for remedial and protective measures, it should be noted that domestic laws do alter the protections for workers who take employment within a FLSA territory.

Although the Truman court's decision is surprising in its reach, it is not without support from statutory and case law, it preserves the right for the states to protect its employee residents, and it can be altered by the Pennsylvania legislature.

133 Id. (citing Reber Taha et al. v. L3 Commc'ns Corp. et al., No. 09-CV 720 (E.D. Va. Nov. 13, 2009)).

134 See, e.g., De Leon-Granados v. Eller \& Sons Trees, Inc., 581 F. Supp. 2d 1295, 1312 (N.D. Ga. 2008) (holding that the FLSA covered claims by migrant workers even before they entered the United States because the costs they incurred to pay for tickets and visas were for the sole benefit of the employer); Arriaga v. Florida Pacific Farms, L.L.C., 305 F.3d 1228, 1235 (11th Cir. 2002) (recognizing the FLSA protections for temporary alien agricultural workers); Garcia v. Frog Island Seafood, Inc., 644 F. Supp. 2d 696 (E.D.N.C. 2009) (finding liability to agricultural workers under both the FLSA and the North Carolina Wage and Hour Act).

135

35 Donald C. Dowling, Jr., International HR Best Practice Tips, 17 No. 3 INT'L HR J. ART 1 (Summer 2008) ("For example, the U.S. seems not to welcome temporary low-wage workers coming in and undercutting Americans on American soil; under the FLSA, an alien working stateside for just 72 hours on non-exempt tasks falls under U.S. wage/hour law and must receive FLSA minimum wage and overtime pay."). 